\title{
Aplikasi Bimbingan Tugas Akhir Menggunakan Notifikasi Berbasis Android
}

\author{
Irma Salamah, Lindawati, Hermika Yuliana Sitompul" \\ Fakultas Teknik Elektro, Teknik Telekomunikasi, Politeknik Negeri Sriwijaya, Palembang, Indonesia \\ Email: ${ }^{1}$ irma.salamah@yahoo.com, ${ }^{2}$ lindawati9111@yahoo.com, ${ }^{* 3}$ mikhays22@gmail.com
}

\begin{abstract}
Abstrak
Pada penelitian ini menyajikan sebuah layanan aplikasi bimbingan tugas akhir (MyAbita) sebagai sistem monitoring untuk melakukan proses bimbingan. Aplikasi ini dibuat dengan memanfaatkan perkembangan teknologi. Aplikasi ini dapat diakses secara online menggunakan android dalam proses komunikasi data. Dalam proses penggunaannya aplikasi ini akan memberikan notifikasi kepada user apabila ada pemberitahuan yang masuk. Dalam proses perancangannya, aplikasi ini dirancang menggunakan metode Rapid Application Development (RAD), sehingga memudahkan dalam proses perancangan aplikasi tersebut. Dalam pengembangan sistemnya, aplikasi ini menggunakan software android studio dan bahasa pemograman yang digunakan adalah Java, $P H P$, dan $X M L$. Dan untuk penyimpanan databasenya menggunakan $M y S Q L$. Aplikasi ini sudah terintegrasi secara online sehingga dapat digunakan oleh mahasiswa/i dalam melakukan proses bimbingan tugas akhir dan dosen juga dapat memonitoring perkembangan proses bimbingan kapan saja.
\end{abstract}

Kata kunci: Tugas Akhir, Android, Notifikasi, Online.

\begin{abstract}
This research provides a final assignment service application (MyAbita) as a monitoring system to carry out the guidance process. This application is made by utilizing technological developments. This application can be accessed online using Android in the data communication process. In the process of using it, this application will notify users. In the design process, this application is designed using the Rapid Application Development (RAD) method, making it easier for the application design process. In developing the system, this application uses android studio software and the programming languages used are Java, PHP, and XML. And for storing the database using MySQL. This application has been integrated online so that it can be used by students in conducting the final assignment guidance process and the lecturer can also monitor the progress of the guidance process at any time.
\end{abstract}

Keywords: Final Project, Android, Notifications, Online.

\section{PENDAhuluan}

Perkembangan teknologi yang semakin hari semakin pesat saat ini, sangat mendukung kinerja manusia dalam berbagai hal, salah satunya dalam proses komunikasi data. Perkembangan teknologi dalam proses komunikasi data saat ini memudahkan manusia memperoleh informasi melalui smartphone atau telepon gengam pintar yang saat ini banyak digunakan. Dalam bidang pendidikan seperti yang ada dalam Perguruan Tinggi baik negeri maupun swasta sangat membutuhkan dukungan dalam proses komunikasi data sebagai sistem informasi dalam peningkatan mutu pelayanan terhadap proses pendidikan. Seperti sistem informasi akademik yang terdiri dari banyak proses antara lain mulai dari perencanaan perkuliahan hingga proses akhir seperti bimbingan tugas akhir.

Tugas akhir merupakan salah satu tahapan akhir yang harus dihadapi oleh mahasiswa/i sebagai syarat untuk menyelesaikan pendidikannya.Tugas akhir bertujuan untuk melatih mahasiswa dalam menggunakan metodologi ilmiah untuk mencari alternatif pemecahan masalah dan mengkomunikasikan kepada pihak-pihak yang terkait baik secara tertulis maupun lisan [1]. Namun kenyataannya sering terjadi masalah dalam proses bimbingan tersebut. Kendala yang sering dihadapi dalam proses bimbingan yaitu seringkali mahasiswa/i dan dosen pembimbing tidak dapat bertemu dikarenakan tidak adanya kecocokan waktu antara kedua belah pihak maupun ketidaktahuan mahasiswa tentang jadwal dosen pembimbing [2].

Maka dari itu, untuk mendukung proses penyampaian informasi secara cepat,tepat dan akurat diperlukan suatu layanan aplikasi bimbingan tugas akhir sebagai sistem informasi yang optimal. Aplikasi ini diharapakan dapat bekerja layaknya bimbingan tugas akhir secara tatap muka namun dengan perantara sistem secara online[2] dengan mengunakan notifikasi yang dijalankan pada perangkat mobile yang memberikan layanan penting untuk membantu mengingatkan user akan tugas yang harus dijalankan [3].

\section{METODE PENELITIAN}

Penelitian ini menggunakan bahasa pemograman Java, PHP, dan $X M L$. Untuk databasenya menggunakan MySQL, dan dalam perancangan Aplikasi Bimbingan Tugas Akhir (MyAbita) berbasis Android dengan fitur notifikasi menggunakan metode Rapid Application Development (RAD). Rapid Application Development $(R A D)$ adalah salah satu metode pengembangan suatu informasi dengan waktu yang relative singkat [4]. Rapid Application Development (RAD) bisa menghasilkan suatu sistem dengan cepat karena sistem yang dikembangkan dapat memenuhi keinginan dari para pemakai sehingga dapat mengurangi waktu untuk pengembangan ulang setelah tahap implementasi. Pengerjaan aplikasi akan dilakukan dengan secara berurutan 
[5]. Urutan atau tahapannya adalah dimulai dari identifikasi masalah, desain layout, kode program, dan pengujian.

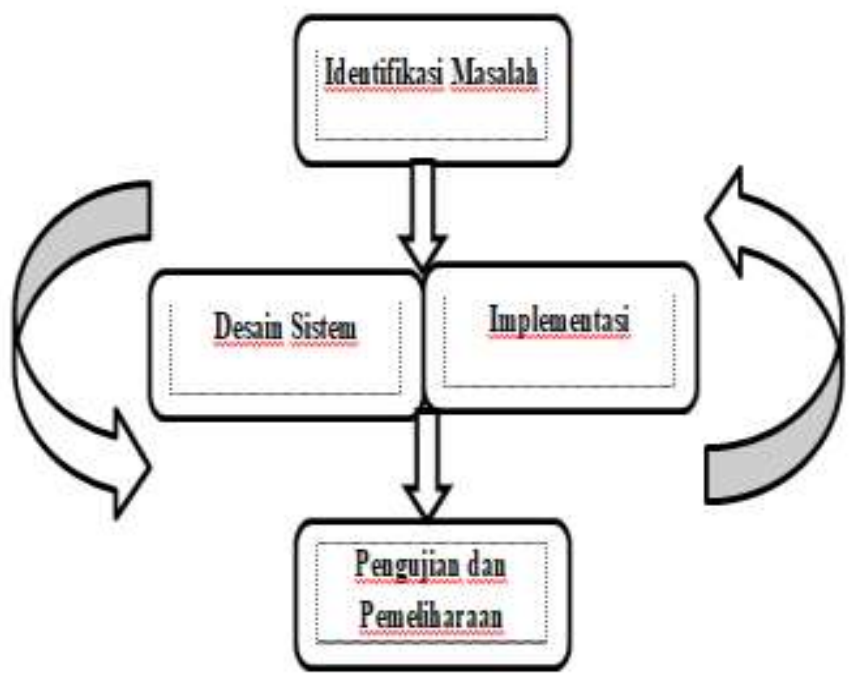

Gambar 1. Metode Penelitian Rapid Application Development (RAD)

1. Identifikasi Masalah : pada tahap ini penulis mengidentifikasi kebutuhan sistem seperti fitur-fitur yang akan disediakan oleh aplikasi. Seperti daftar mahasiswa, daftar pembimbing, proses bimbingan, dan pengumuman yang dibutuhkan untuk membuat aplikasi tersebut.

2. Desain Sistem : pada tahap ini penulis mementukan desain dan tahapan untuk membangun aplikasi. Penulis menentukan bentuk layout, gambar dan warna pada setiap halaman yang ada dalam aplikasi

3. Implementasi : pada tahap ini penulis mulai menerapkan pembuatan deain sistem kedalam bentuk pemograman, yakni menggunakan bahasa program $X M L$ dan Java.

4. Pengujian dan Pemeliharaan : pada tahap ini merupakan tahapan akhir dalam proses pembuatan aplikasi. Menguji apakah hasil dari implementasi desain tersebut sudah berjalan dengan baik pada sistem operasi android.

\section{ANALISA DAN PEMBAHASAN}

Diagram Activity adalah pemodelan perangkat lunak yang menunjukkan alur kontrol atau aliran objek dengan penekanan pada urutan dan kondisi aliran. Rancangan diagram activity untuk pengembangan Aplikasi Android Bimbingan Tugas Akhir (MyAbita) dapat dilihat pada Gambar 2 untuk pemodelan diagram activity dosen, Gambar 3 pemodelan activity diagram mahasiswa.

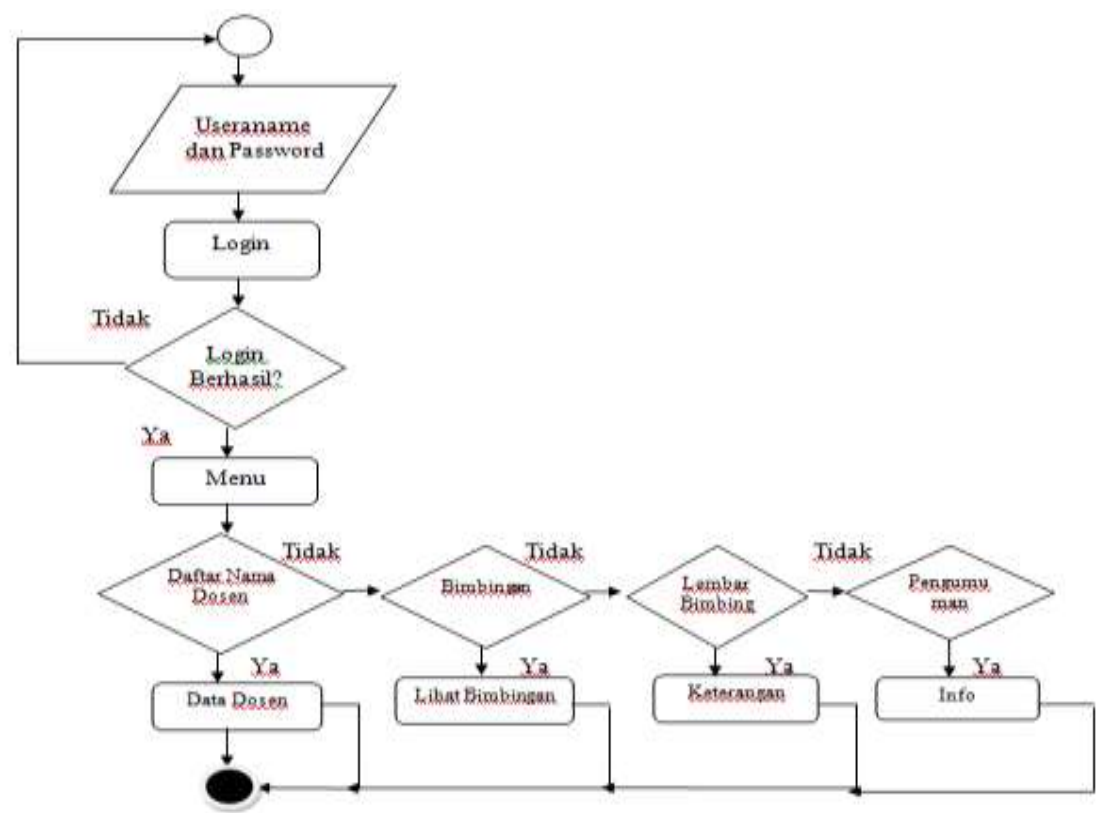

Gambar 2. Diagram Activity activity mahasiswa 


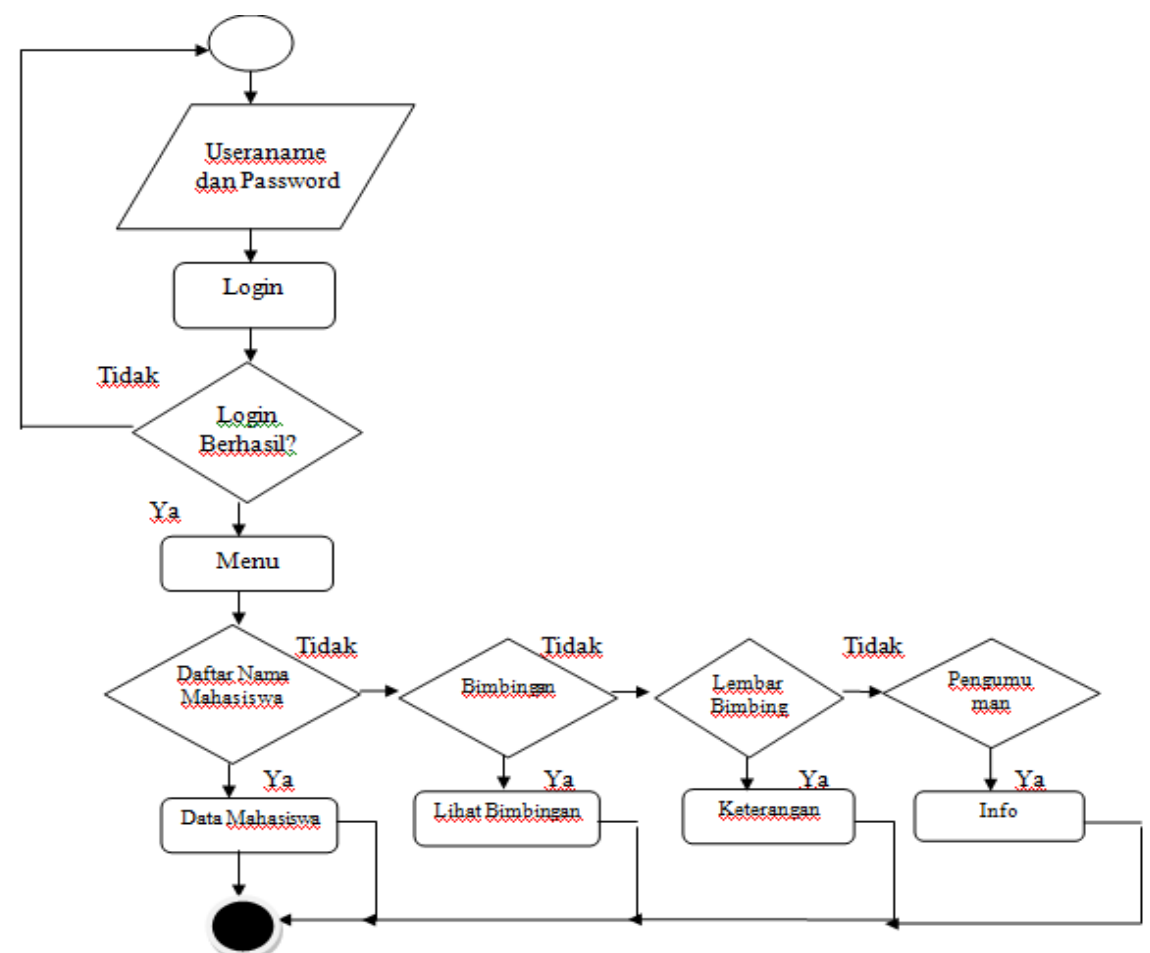

Gambar 3. Diagram activity dosen

\section{IMPLEMENTASI}

Pada penelitian ini menghasilkan aplikasi yang terintegrasi secara online dengan system informasi berbasis android yang berfungsi sebagai media untuk memudahkan dalam melakukan proses bimbingan Tugas Akhir mahasiswa dengan dosen pembimbingnya secara online sehingga membuat proses bimbingan dapat dilakukan dalam secara efektif dan efisien.

\section{A. Tampilan Dari Setiap Halaman Yang Ada Pada Aplikasi}

a. Tampilan Localhost

Localhost adalah server lokal yang ada padai komputer. Localhost adalah hostname dari komputer itu sendiri. Localhost dapat diakses ketika ada web server yang berjalan. Locallhost ini berisi table-tabel yang digunakan untuk membuat aplikasi tersebut. Tabel tersebut terdiri dari tabel mahasiswa, tabel dosen, tabel konsultasi, dan tabel informasi. Tampilan halaman locallhost dapat dilihat pada gambar dibawah ini :

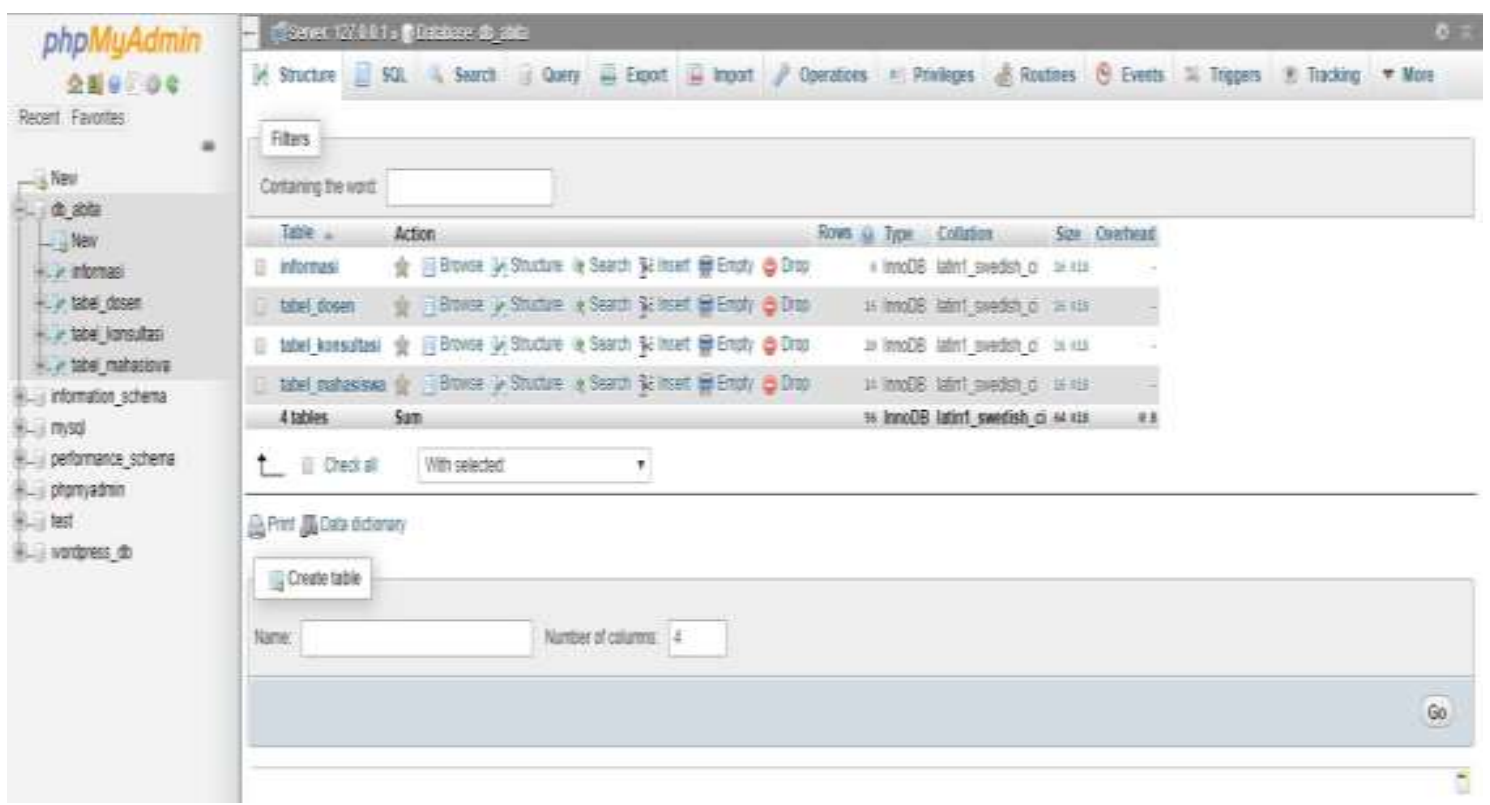

Gambar 4. Halaman Locallhost 
b. Tampilan Halaman Android Studio

Pada halaman ini merupakan platform untuk membuat code aplikasi pada android dengan menggunakan bahasa pemograman java dan $x m l$. Bahasa program java digunakan untuk membuat perintah kerja aplikasi sedangkan bahasa program $x m l$ digunakan untuk membuat layout aplikasi yang akan dibuat.



Gambar 5. Tampilan Halaman Android Studio

c. Tampilan Splash Screen

Ini merupakan tampilan awal dari penggunaan aplikasi sebelum masuk/ login ke aplikasi tersebut. Halaman ini berisi tampilan logo dari aplikasi MyAbita. Tampilan tersebut dapat dilihat pada gambar dibawah ini :

\section{MY ABITA}

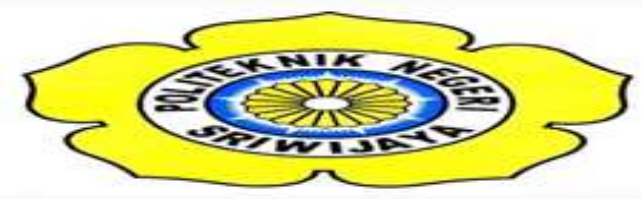

Welcome MYABITA

\section{Gambar 6. Halaman Splashscreen}

d. Tampilan Login Mahasiswa / Dosen

Ini merupakan tampilan halaman untuk login mahasiswa / dosen. Untuk dapat masuk mengakses aplikasi tersebut mahasiswa / dosen cukup memasukan NIM untuk mahasiswa, NIP untuk dosen serta passwordnya masing-masing dan memilih status sesuai dengan kebutuhannya.. Tampilan halaman login dapat dilihat pada gambar dibawah ini :

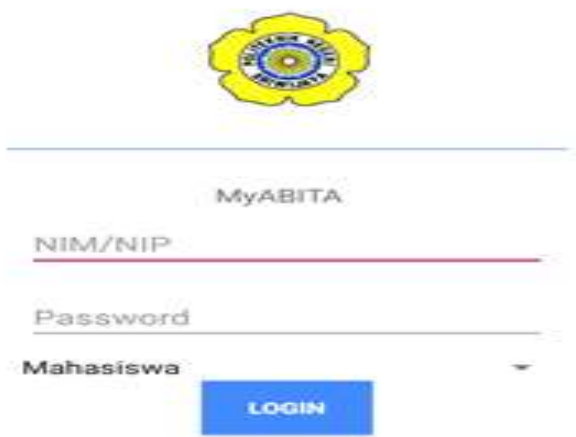

Gambar 7. Halaman Login 
e. Tampilan Menu Utama

Pada halaman menu utama ini terdapat 3 pilihan. Untuk dosen terdiri dari menu bimbingan, pengumuman, dan exit. Untuk mahasiswa terdiri dari menu bimbingan, pengumuman dan exit. Setiap tampilan tentunya memiliki fungsinya yang berbeda-beda. Tampilan halaman menu utama dapat dilihat pada gambar dibawah ini :

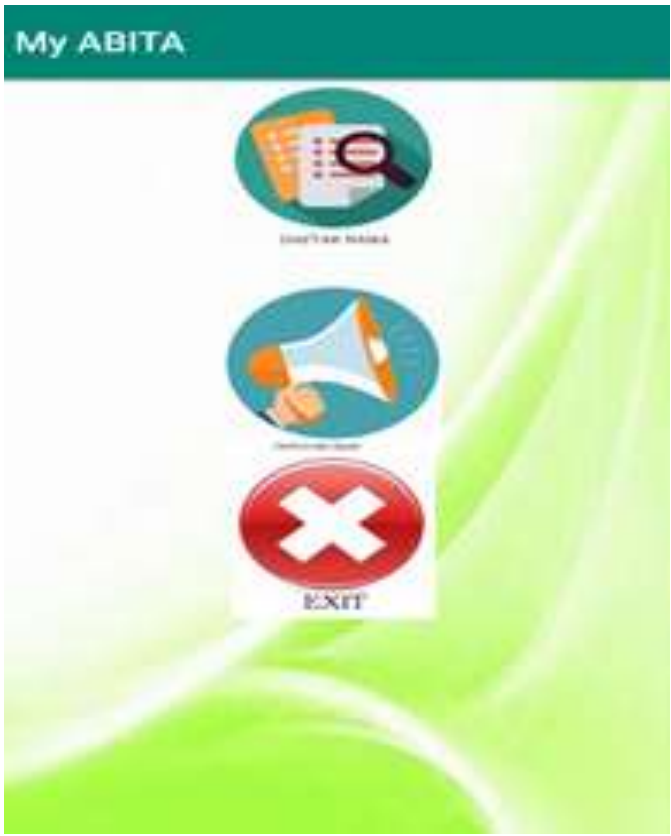

Gambar 8. Halaman Menu Dosen



Gambar 9. Halaman Menu Mahasiswa

f. Tampilan Menu Bimbingan Untuk Mahasiswa

Pada menu halaman bimbingan mahasiswa, terdapat pilihan untuk memilih dosen pembimbing satu atau pembimbing ke dua, mengupload file, dan mengecek pengumuman. Tampilan ini dibuat dengan menggunakan List View yang ada pada android studio. ListView adalah user interface pada Android Studio yang menampilkan item-item dari sekumpulan daftar yang tersusun berbaris ke bawah atau kesamping dengan tampilan yang dapat scroll.

\section{My ABITA}

\section{Pilih Pembimbing}

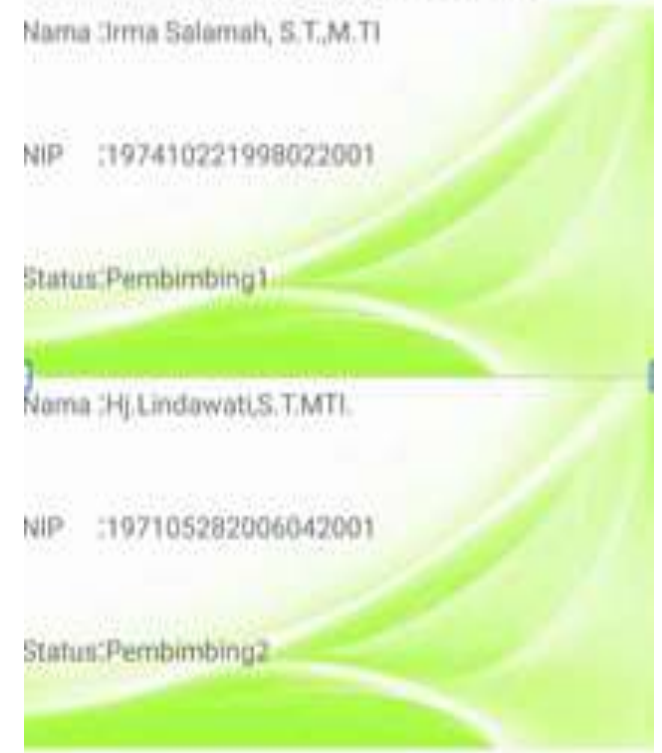

Gambar 10. Halaman Pilih Pembimbing

\section{My ABITA}

\section{Keterangan Bimbingan}

\begin{tabular}{|c|c|}
\hline & TAMBAH \\
\hline ID & 361 \\
\hline NIM & 061540352249 \\
\hline NIP & 197410221998022001 \\
\hline Tanggal Upload & $2019 \cdot 05 \cdot 2320,57: 47$ \\
\hline File & 1557753517037 Modul 2docx \\
\hline Utaian Bimbingar & rLatar belakanc, tujuan dan manfa \\
\hline Tanggal Respon & $0000-00-0000.0000$ \\
\hline $\mathrm{BAB}$ & BAB 1 \\
\hline Suatus: & : \\
\hline ID & 369 \\
\hline NiM & 2061540352249 \\
\hline NIP & .197410221998022001 \\
\hline Tanggal Upload & $2019-05-2320,56.51$ \\
\hline File: & 1558402927896.Madul 5.doox \\
\hline Uraian Bimbinga: & n:Diperbakik lebih baik \\
\hline Tenogai Respon & $=0000-00-00000000$ \\
\hline BAB & BAB 5 \\
\hline Stahes: & $i$ \\
\hline
\end{tabular}

Gambar 11. Halaman List View Bimbingan 


\section{MY ABITA}

\section{Pengumuman}



Gambar 12. Halaman Pengumuman

g. Tampilan Menu Bimbingan Untuk Dosen

Pada menu halaman bimbingan dosen, terdapat pilihan untuk memilih mahasiswa bimbingan, mendownload file dan ,revisi dan upload pengumuman. Tampilan ini dibuat dengan menggunakan List View yang ada pada android studio.

\section{My ABITA}

\section{Daftar Nama}



Gambar 13. Halaman Pilih Mahasiswa/i

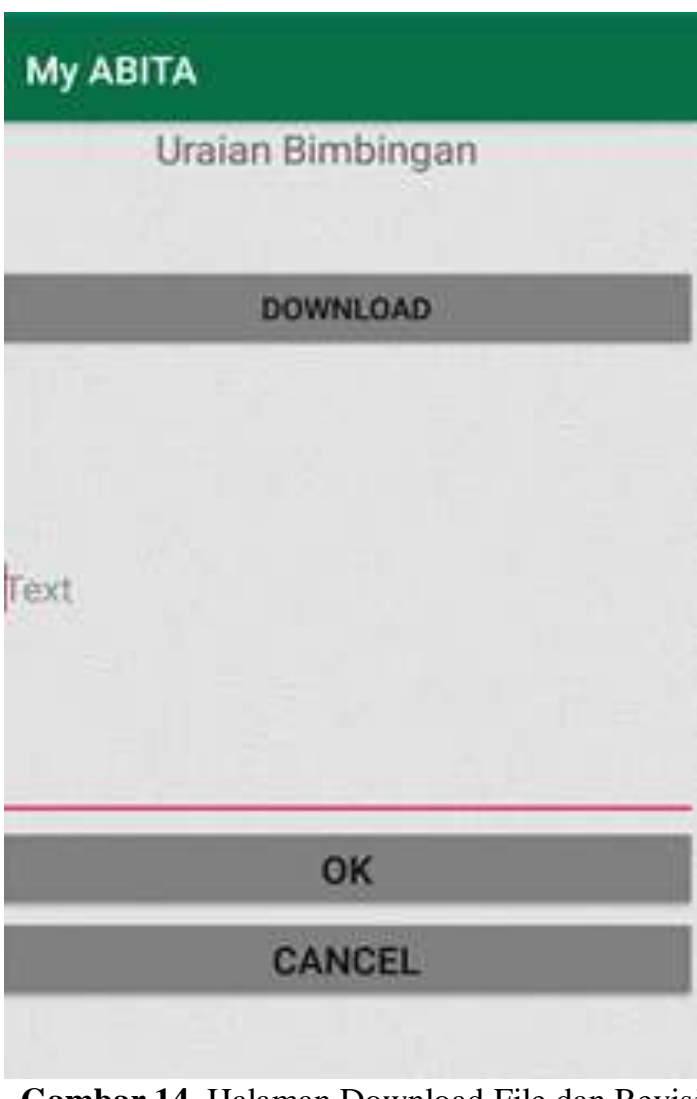

Gambar 14. Halaman Download File dan Revisi 


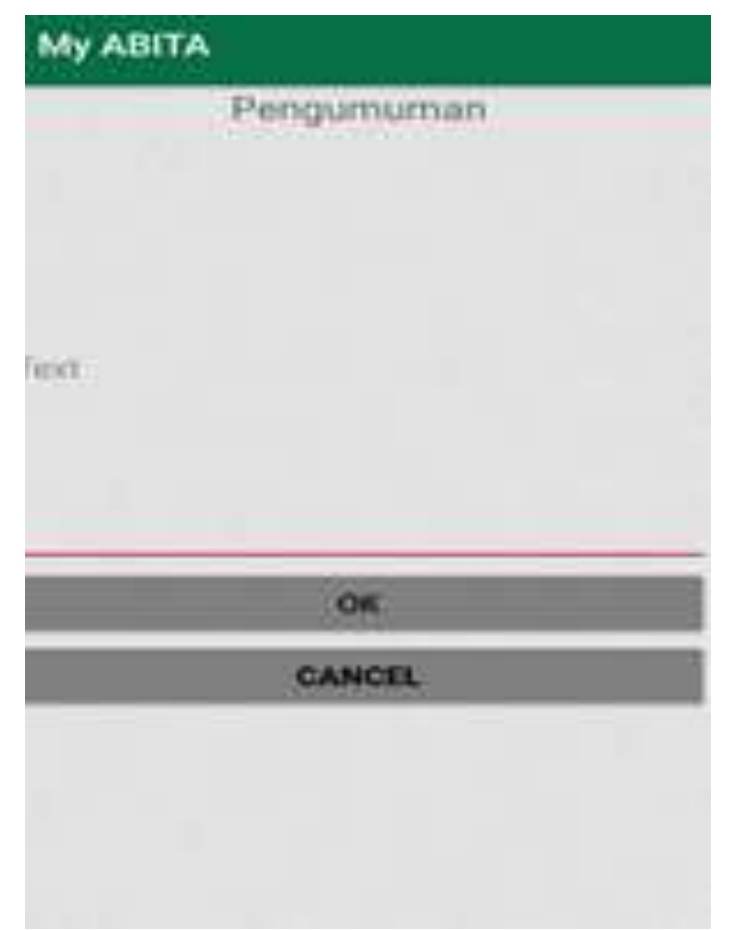

Gambar 15. Halaman Mengirim Pengumuman

\section{My ABITA}

\section{Pengumuman}



Gambar 16. Halaman list view pengumuman

h. Tampilan Notifikasi

Ini merupakan tampilan notifikasi yang masuk secara otomatis pada perangkat telphone seluler. Notifikasi akan ada jika ada pemberitahuan mengenai revisi atau informasi jadwal bimbingan yang masuk.

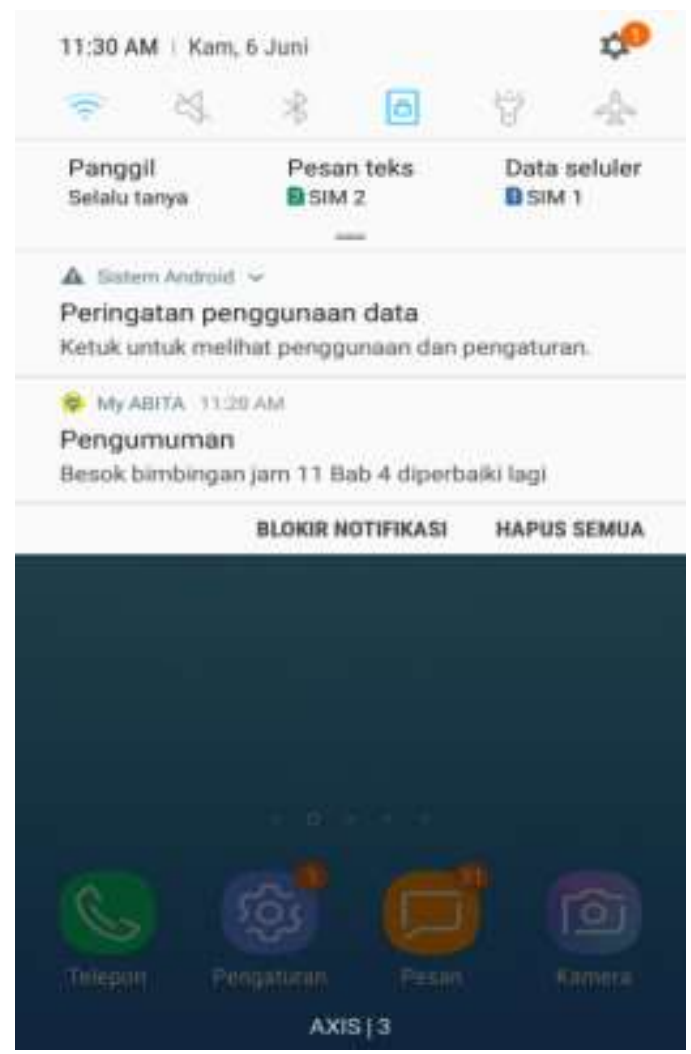

Gambar 17. Tampilan Notifikasi

\section{B. Pengujian Fungsional Dari Setiap halaman Aplikasi}

Pengujian setiap halaman tahapan pada aplikasi ini dilakukan untuk mengetahui kesesuaian antara sistem yang telah dirancang di awal dengan fungsional sistem yang telah dibuat. 
Tabel 1. Hasil Pengujian Fungsional Aplikasi

\begin{tabular}{llcc}
\hline \multirow{2}{*}{ No. } & Halaman yang Diuji & \multicolumn{2}{c}{ Hasil Pengujian } \\
& Berhasil & Gagal \\
\hline 1. & Splash Screen & $\mathrm{v}$ & - \\
2. & Login & $\mathrm{v}$ & - \\
& Menu Utama Mahasiswa $/$ & $\mathrm{V}$ & - \\
3. & Dosen & & - \\
4. & Menu Bimbingan & $\mathrm{V}$ & - \\
5. & Notifikasi & $\mathrm{v}$ & - \\
\hline
\end{tabular}

\section{KESIMPULAN}

Dari penelitian dapat disimpulkan:

1. Pada penelitian ini telah dihasilkan sebuah aplikasi yang dapat digunakan untuk melakukan proses bimbingan Tugas Akhir yang terintegrasi secara online antara mahasiswa dengan dosen pembimbingnya.

2. Dengan memanfatkan android sebagai sistem operasi ini merupakan pengembangan dari pernelitian sebelumnya yang hanya dikembangkan dalam bentuk website.

3. Aplikasi Android Bimbingan Tugas Akhir dengan fitur notifikasi berfokus pada mengetahui pentingnya fitur notifikasi pada aplikasi, memvalidasi bimbingan tugas akhir, edit bimbingan tugas akhir, dan memberikan notifikasi pada bimbingan baru dan bimbingan yang telah divalidasi.

\section{REFERENCES}

[1] Nastiti,F.E., \& Susanto. Prototype Aplikasi Layanan Monitoring Bimbingan Skripsi/Tugas Akhir Menggunakan Service Oriented Architecture Framework. Duta.com ISSN : 2086-9436 Volume 7 Nomor 2 September 2014.

[2] Dwiyani, Aprillita. (2013). Perancangan Sistem Pendukung Bimbingan Online Tugas Akhir Mahasiswa Program Studi Teknik Informatika, Skripsi tidak dipublikasikan. Universitas Tanjungpura.

[3] Ramadhan.T., \& Victor.G.U . (2014) Rancang Bangun Aplikasi Mobile Untuk Notifikasi Jadwal Kuliah Berbasis Android (Studi Kasus: STMIK Provinsi Semarang). Jurnal Teknologi Informasi dan Komunikasi 5.2: 47-55, 2014

[4] Meidyan Permata P., \& Hendra E .Implementasi Metode Rapid Application Development Pada Website Service Guide "Waterfall Tour South Sumatera”. Jurnal SISFOKOM, Volume 07, Nomor 02, September 2018.

[5] Jijon R. S. Model Rapid Application Development (Rad) Dalam Pengembangan Sistem Informasi Penjadwalan Belajar Mengajar. Jurnal Mantik Penusa Vol. 2, No. 1 Juni 2018, pp. 87-90. 